\title{
Experimental infections reveal that common Thai crustaceans are potential carriers for spread of exotic Taura syndrome virus
}

\author{
Wansika Kiatpathomchai ${ }^{1,2, *}$, Wansadaj Jaroenram ${ }^{2}$, Narong Arunrut ${ }^{1,2}$, \\ Warachin Gangnonngiw ${ }^{1,2}$, Visanu Boonyawiwat ${ }^{3}$, Paisarn Sithigorngul ${ }^{4}$ \\ ${ }^{1}$ National Center for Genetic Engineering and Biotechnology (BIOTEC), National Science and Technology Development \\ Agency, Pathumthani 12120, Thailand \\ ${ }^{2}$ Center of Excellence for Shrimp Molecular Biology and Biotechnology (CENTEX Shrimp), Faculty of Science, \\ Mahidol University, Rama 6 Road, Bangkok 10400, Thailand \\ ${ }^{3}$ Department of Farm Animal Resource and Production Medicine, Faculty of Veterinary Medicine, Kasetsart University, \\ Kamphaengsaen Campus, Nakhonpathom 73140, Thailand \\ ${ }^{4}$ Department of Biology, Faculty of Science, Srinakharinwirot University, Bangkok 10110, Thailand
}

\begin{abstract}
Taura syndrome virus (TSV) was first reported as a serious cause of shrimp mortality limited to reared Penaeus (Litopenaeus) vannamei in the Americas, where it spread principally through regional and international transfer of live post larvae (PL) and broodstock. Subsequently, through importation of infected broodstock, TSV outbreaks spread to Asia, first to Taiwan and China and then to Thailand, Indonesia and Korea. Since its introduction to Thailand, outbreaks have occasionally been reported from rearing ponds stocked with batches of specific pathogen free (SPF) $P$. vannamei PL that tested negative for TSV by nested RT-PCR assay. Since it was possible that the outbreaks may have occurred via horizontal transfer of TSV from wild carrier species, we tested 5 common native crustaceans that live in and around shrimp ponds (2 palaemonid shrimp species, Palaemon styliferus and Macrobrachium lanchesteri, and 3 species of crabs, Sesarma mederi, Scylla serrata and Uca vocans) for susceptibility to TSV in experimental challenges. We found that $U$. vocans, $S$. serrata and $S$. mederi did not die but, respectively, gave strong RT-PCR reactions indicating heavy viral load at 5,10 and $15 \mathrm{~d}$ post-injection of TSV and 10,15 and up to $50 \mathrm{~d}$ after feeding with TSV-infected $P$. vannamei carcasses. Also after feeding, $P$. styliferus did not die, but a high proportion gave strong RT-PCR reactions at $5 \mathrm{~d}$ post-challenge and no reactions at $15 \mathrm{~d}$. Similarly after feeding, $M$. lanchesteri showed no mortality and gave only light RT-PCR reactions at $2 \mathrm{~d}$, moderate reactions at $5 \mathrm{~d}$ and no reaction at $15 \mathrm{~d}$. By contrast, transmission experiments from the TSV-infected crabs and palaemonid shrimp via water or feeding resulted in death of all the exposed $P$. vannamei from 8 to $12 \mathrm{~d}$ post-challenge and all were positive for heavy viral load by RT-PCR assay. Despite the results of these laboratory challenge tests, natural TSV infections were not detected by nested RT-PCR in samples of these species taken from the wild. These results indicated that transmission of TSV from infected crabs and palaemonid shrimp via water or feeding might pose a potential risk to shrimp aquaculture.
\end{abstract}

KEY WORDS: TSV • Taura syndrome virus · Penaeus vannamei · Crab · Palaemonid shrimp · Carrier $\cdot$ RT-PCR

Resale or republication not permitted without written consent of the publisher

\section{INTRODUCTION}

Taura syndrome (TS) was first reported from Ecuador in 1992 (Jimenez 1992). It was a serious cause of shrimp mortality for reared Penaeus (Litopenaeus) vannamei in the Americas where it spread principally through the re- gional and international transfer of live post larvae (PL) and broodstock (Brock et al. 1995). Its viral etiology was discovered in 1995 (Brock et al. 1995, Hasson et al. 1995). Taura syndrome virus (TSV) is a small, non-enveloped icosahedral virus containing a single-stranded, positivesense RNA genome of 10205 nucleotides (Hasson et 
al. 1995, Bonami et al. 1997, Mari et al. 2002). Its protein capsid consists of 3 major polypeptides $(55,40$ and $24 \mathrm{kDa}$ designated VP1, VP2 and VP3, respectively) and 1 minor polypeptide (58 kDa designated V0) (Bonami et al. 1997, Mari et al. 2002). TSV has been placed in the family Dicistroiridae (Mayo 2002, 2005).

TSV can infect several shrimp species including Penaeus (Litopenaeus) stylirostris, Penaeus (Litopenaeus) setiferus (Overstreet et al. 1997, Erickson et al. 2002), Penaeus monodon (Chang et al. 2004, Nielsen et al. 2005), Penaeus (Marsupenaeus) japonicus and Macrobrachium rosenbergii (Nielsen et al. 2005). A wider host range has been demonstrated for white spot syndrome virus (WSSV) by polymerase chain reaction (PCR) and in situ hybridization. It includes penaeid shrimp, crabs, palaemonid shrimp, krill, crayfish and copepods (Lo et al. 1996, Supamattaya et al. 1998, Kanchanaphum et al. 1998, Peng et al. 1998, Chen et al. 2000, Maeda et al. 2000, Jiravanichpaisal et al. 2001). There are also multiple hosts for yellow head virus (YHV), as shown by RT-PCR detection and immunohistochemistry. Hosts include 3 common palaemonid species (Macrobrachium sintangense, Palaemon styliferus and Palaemon serrifer) (Longyant et al. 2005).

Since TSV has been recently introduced to Thailand and has caused numerous disease outbreaks in shrimp ponds where Penaeus (Litopenaeus) vannamei is being reared, it is possible that native crustaceans have also become infected with the virus. If so, they could constitute a natural viral reservoir that presents some risk to shrimp farmers. Thus, it was of interest to use RT-PCR amplification to search for potential, native TSV carriers such as crabs and palaemonid shrimp that live in and around $P$. vannamei rearing ponds. We also tested some common crabs (Sesarma mederi, Uca vocans and Scylla serrata) and 2 palaemonid shrimp (Palaemon styliferus and Macrobrachium lanchesteri) for susceptibility to TSV in laboratory challenge tests. Detection by RT-PCR was confirmed by immunohistochemistry using a polyclonal antibody specific to the capsid protein VP1 of TSV. It was hoped that identification of carriers would assist shrimp farmers in implementing control measures to exclude them from the cultivation system and prevent horizontal transmission of TSV.

\section{MATERIALS AND METHODS}

Shrimp and crab specimens. Two palaemonid shrimp species (Palaemon styliferus and Macrobrachium lanchesteri) ( $<1 \mathrm{~g}$ each) were collected from a Penaeus (Litopenaeus) vannamei farm and nearby canals in Samutsongkhram province. Sesarma mederi $(\sim 30 \mathrm{~g}$ each) specimens were collected from $P$. vannamei farms in Chantaburi and Samutsongsongkhram provinces. Uca vocans ( $\sim 30 \mathrm{~g}$ each) and Scylla serrata ( $300 \mathrm{~g}$ each) were collected from mangrove forests near $P$. vannamei farms in Samutsongkhram and Samutsakorn provinces.

Penaeus (Litopenaeus) vannamei ( 20 g each) used in TSV transmission tests were obtained from a shrimp farm in Samutsongsongkhram province. The collected crustaceans were acclimatized in the laboratory for $2 \mathrm{~d}$ in 651 aquaria containing continuously aerated artificial seawater at $15 \mathrm{ppt}$ and 30 to $35^{\circ} \mathrm{C}$. Palaemonid shrimp were fed on a dry commercial shrimp feed diet and crabs were fed with uninfected TSV $P$. vannamei carcasses once daily. Challenge tests and transmission tests were carried out under the same conditions.

TSV challenge tests. A TSV viral stock solution was prepared from infected Penaeus (Litopenaeus) vannamei haemolymph and diluted with lobster haemolymph buffer (LHB) according to Boonyaratpalin et al. (1993). The TSV-infected shrimp were obtained from an outbreak farm in Samutsakorn province of Thailand. For each species of crab (Sesarma mederi, Uca vocans and Scylla serrata), 10 were injected with $100 \mu \mathrm{l}$ of viral stock solution, 10 were fed with TSVinfected shrimp carcasses $(15 \%$ body weight as described by Tsai et al. 2002) and 10 were not exposed to TSV and held as negative controls. The crustaceans were placed in $65 \mathrm{l}$ aquaria containing continuously aerated artificial seawater at $15 \mathrm{ppt}$. They were then assayed at $2 \mathrm{~d}, 5 \mathrm{~d}, 10 \mathrm{~d}, 15 \mathrm{~d}, 40 \mathrm{~d}$ and $50 \mathrm{~d}$ by taking $150 \mu \mathrm{l}$ of haemolymph from 5 arbitrarily selected individuals and mixing it individually with $300 \mu \mathrm{l}$ of $\mathrm{AC} 1$ solution $(450 \mathrm{mM} \mathrm{NaCl}, 30 \mathrm{mM}$ Trisodium citrate, $26 \mathrm{mM}$ Citric acid, $12.7 \mathrm{mM}$ EDTA, $100 \mathrm{mM}$ Glucose, $\mathrm{pH}$ 7.0). At termination of the experiment (Day 50), hemocytes of all remaining animals were tested for TSV infection by immunofluorescence using confocal microscopy.

Since the palaemonid shrimp (Palaemon styliferus and Macrobrachium lanchesteri) were too small $(<1 \mathrm{~g}$ each) for injection challenge, 80 individuals from each species were fed with $12 \mathrm{~g}$ (15\% body weight as described by Tsai et al. 2002) of chopped TSV-infected Penaeus (Litopenaeus) vannamei carcasses and 80 were fed with dry commercial shrimp feed diet as negative controls. The palaemonid shrimp were reared in 651 aquaria containing continuously aerated artificial seawater at $15 \mathrm{ppt}$ for $50 \mathrm{~d}$. Whole bodies of 5 individuals were arbitrarily selected at each sampling interval and homogenized in $500 \mu \mathrm{l}$ of TRI Reagent ${ }^{\circledR}$ (Molecular Research Center) for RNA extraction.

RNA extraction. Total RNA from crabs was extracted from $450 \mu \mathrm{l}$ of haemolymph-AC1 mixture by vigorous mixing in $500 \mu \mathrm{l}$ of TRI Reagent ${ }^{\circledR}$, while total RNA from whole bodies of small palaemonid shrimp was extracted by grinding in $500 \mu \mathrm{l}$ of TRI Reagent ${ }^{\circledR}$. After incubation 
for $5 \mathrm{~min}, 200 \mu \mathrm{l}$ chloroform was added with vigorous mixing, and the tube was incubated for $10 \mathrm{~min}$ before centrifugation at $12000 \times g$ for $10 \mathrm{~min}$. The aqueous phase was transferred to a fresh tube followed by addition of $500 \mu \mathrm{l}$ of $100 \%$ isopropanol with gentle mixing. After incubation for $10 \mathrm{~min}$ at $25^{\circ} \mathrm{C}$ the tube was centrifuged at $12000 \times g$ for $10 \mathrm{~min}$, and the pellet was washed with $70 \%$ (v/v) ethanol, air dried and dissolved in $50 \mu$ l of RNase-free water. RT-PCR amplification was carried out using $2 \mu \mathrm{l}$ of this RNA solution as template.

RT-PCR detection of TSV. Extracted RNA was amplified by RT-PCR using the IQ2000 ${ }^{\mathrm{TM}}$ TSV Detection and Prevention System (Farming IntelliGene Technology Corporation) according to the manufacturer's protocol. The nested PCR products were detected by $1.8 \%$ agarose gel electrophoresis with ethidium bromide with visualization on a UV transilluminator. Results were interpreted using the kit guidelines as follows: appearance of 3 amplicons at $284 \mathrm{bp}, 476 \mathrm{bp}$ and above $848 \mathrm{bp}$ indicated a heavy viral load (+++); 2 amplicons at $284 \mathrm{bp}$ and $476 \mathrm{bp}$ indicated a medium viral load (++); 1 amplicon at $284 \mathrm{bp}$ with or without the housekeeping band at $680 \mathrm{bp}$ indicated a light viral load $(+) ; 1$ band only at $680 \mathrm{bp}$ (housekeeping gene) was considered to be a negative test result for TSV (-) within the sensitivity of the test (20 copies of TSV genome per RT-PCR reaction vial).

Confirmation of TSV infections by immunofluorescence and confocal microscopy. Haemolymph of crabs at $50 \mathrm{~d}$ post-challenge with TSV was fixed with $4 \%$ formaldehyde in PBS (137 mM NaCl, $10 \mathrm{mM}$ phosphate, $2.7 \mathrm{mM} \mathrm{KCl}, \mathrm{pH} 7.4$ ) for $30 \mathrm{~min}$. They were washed 3 times with PBS, permeabilized with $0.1 \%$ Triton X-100 for 10 min and blocked with $10 \%$ normal bovine serum for $30 \mathrm{~min}$. After incubation with a primary antibody specific to the capsid protein (VP1) as validated in a previous study (Chaivisuthangkura et al. 2006) for $1 \mathrm{~h}$, they were washed with PBS-T (0.1\% Tween 20 in PBS). They were incubated with GAM Alexa Fluor 546 (Molecular probe) (1:500) for $30 \mathrm{~min}$ and washed with PBS-T for $5 \mathrm{~min}$. This was followed by a second fixation in $4 \%$ formaldehyde in PBS for $15 \mathrm{~min}$ and counterstaining with To-Pro 3 (Molecular probe) (1:500) nuclear stain for $1 \mathrm{~h}$ before a final wash with PBS. The cells were then examined by confocal microscopy. Positive controls consisted of stained hemocytes from TSV-infected Penaeus (Litopenaeus) vannamei, and negative controls consisted of stained hemocytes from $P$. vannamei that tested negative for TSV by RT-PCR.
Preliminary experimental transmission tests. To test whether TSV could be transmitted from crabs to Penaeus (Litopenaeus) vannamei by water, 3 experimentally infected Sesarma mederi (separate from the crabs described above) were placed (15 d post-injection with TSV inoculum) in a 651 aquarium in a basket to separate them from 5 uninfected $P$. vannamei. Haemolymph was collected from each shrimp at $5 \mathrm{~d}$ and assayed by RT-PCR for TSV as described above. A similar protocol was used to test whether TSV could be transmitted from the palaemonid shrimp to $P$. vannamei by water. Five Macrobrachium lanchesteri fed with TSV-infected $P$. vannamei carcasses at $5 \mathrm{~d}$ postchallenge were placed in a basket in an aquarium containing 5 uninfected $P$. vannamei. For control groups, 5 uninfected $P$. vannamei were incubated under identical conditions without exposure to TSV.

In addition, to test whether TSV could be transmitted from infected crabs and palaemonid shrimp to Penaeus (Litopenaeus) vannamei orally, 15 g (15\% total body weight $P$. vannamei) of carcasses of TSV-infected Sesarma mederi and infected Macrobrachium lanchesteri were fed to 5 uninfected $P$. vannamei (20 g each). Haemolymph was removed from each $P$. vannamei for RT-PCR testing at $5 \mathrm{~d}$ after feeding.

\section{RESULTS}

\section{Natural infections}

For each crustacean species, 10 to 40 individuals were used to detect natural TSV infection using the IQ2000 ${ }^{\mathrm{TM}}$ Detection and Prevention System. None of the natural specimens of crustaceans collected gave positive test results for TSV infection (Table 1). Although there is no information available to indicate the epidemiological sensitivity and specificity of the

Table 1. Results of screening natural crustaceans for Taura syndrome virus (TSV) by nested RT-PCR using the IQ2000 ${ }^{\mathrm{TM}}$ TSV detection kit. Assuming test sensitivity and specificity at $100 \%$ and populations of more than 100000 (not necessarily valid assumptions), this would indicate freedom from TSV at the target prevalences (\%) shown

\begin{tabular}{|llcc|}
\hline Species & Province & $\begin{array}{c}\text { No. of TSV- } \\
\text { negative } \\
\text { samples }\end{array}$ & $\begin{array}{c}\text { Target } \\
\text { prevalence } \\
(\%)\end{array}$ \\
\hline Palaemon styliferus & Samutsongkhram & 40 & 8 \\
Macrobrachium lanchesteri & Samutsongkhram & 40 & 8 \\
Sesarma mederi & Chantaburi & 20 & 14 \\
Uca vocans & Samutsongsongkhram & 15 & 19 \\
\multirow{2}{*}{ Scylla serrata } & Samutsongkhram & 20 & 14 \\
& Samutsakorn & 15 & 19 \\
& Samutsongkhram & 10 & 26 \\
& Samutsakorn & 10 & 26 \\
\hline
\end{tabular}


IQ2000 test, crude calculations on freedom from disease were calculated for each sample (Cameron 2002) assuming that sensitivity and specificity were both $100 \%$, that the target populations in each area were over 100000 and that the samples were random. The results for a total of 170 samples indicated freedom from TSV at $2 \%$ prevalence. To obtain a precise idea of the level of prevalence in these populations, a more rigorous sampling and testing protocol would be required. We did not test these wild specimens for the presence of other shrimp viruses since the intention was to determine the prevalence of TSV only.

\section{Experimental infections}

RT-PCR analysis of haemolymph samples from crabs challenged with TSV by injection (Fig. 1, Table 2) revealed that all 5 Sesarma mederi specimens had light viral loads at $2 \mathrm{~d}$ post-challenge and heavy viral loads at 15 d post-challenge. All 5 Uca vocans had light

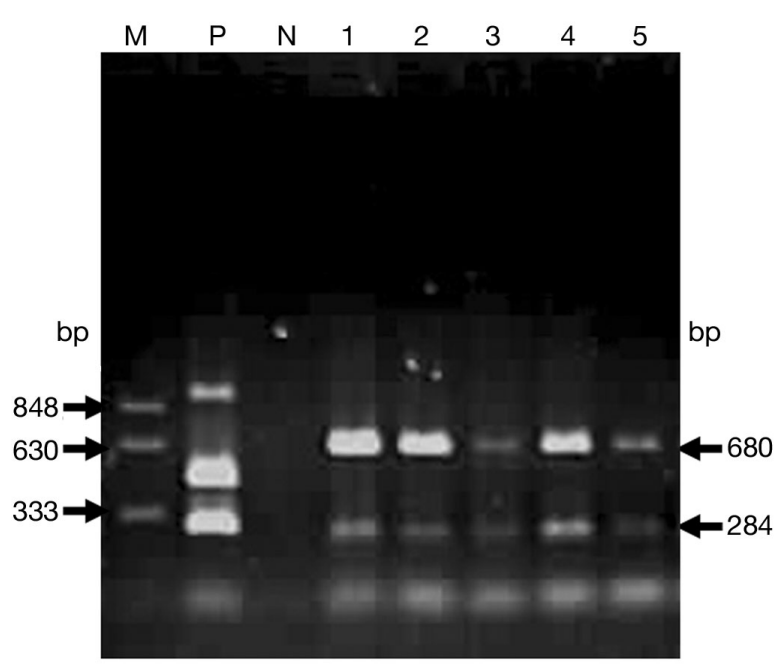

Fig. 1. Sample agarose gel of RT-PCR products (IQ2000 ${ }^{\mathrm{TM}}$ TSV detection kit) from haemolymph of 5 Sesarma mederi at $2 \mathrm{~d}$ post-injection of TSV. Lane M: molecular weight marker. Lane P: positive control (TSV plasmid). Lane N: negative control. PCR products of 284 and $680 \mathrm{bp}$ (housekeeping gene) indicate a light infection of TSV viral loads at $2 \mathrm{~d}$ post-challenge and heavy viral loads at 5 d post-challenge. Scylla serrata gave strong RTPCR reactions indicating heavy viral loads at $10 \mathrm{~d}$ postchallenge.

RT-PCR assays of crabs orally challenged with TSVinfected Penaeus (Litopenaeus) vannamei carcasses (Fig. 2, Table 3) revealed that 3 of 5 Sesarma mederi had light viral loads at $5 \mathrm{~d}$ post-challenge, 4 of 5 had medium viral loads at $10 \mathrm{~d}$ post-challenge and 5 of 5 had heavy viral loads at $50 \mathrm{~d}$ post-challenge. At $5 \mathrm{~d}$ post-challenge, 4 of 5 Uca vocans showed light viral loads, and 3 of 5 showed heavy viral loads at $10 \mathrm{~d}$ postchallenge. At 15 d post-challenge, 4 of 5 Scylla serrata showed heavy viral loads. For control groups, all crabs survived and gave negative RT-PCR reactions for TSV at 2, 5, 40 and $50 \mathrm{~d}$.

RT-PCR assays of the palaemonid shrimp Palaemon styliferus and Macrobrachium lanchesteri challenged by feeding with TSV-infected Penaeus vannamei carcasses (Fig. 3, Table 3) revealed light viral loads for all 5 individuals of both species at $2 \mathrm{~d}$ post-challenge. At

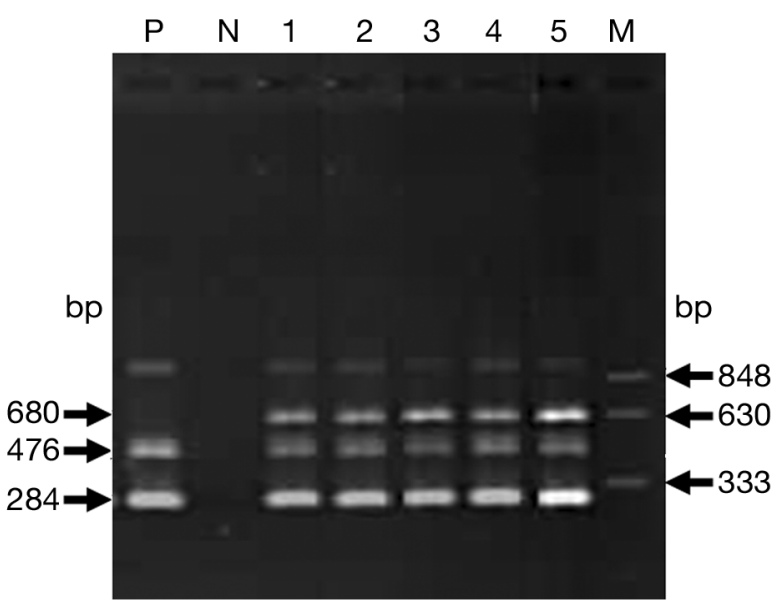

Fig. 2. Sample agarose gel of RT-PCR (IQ2000 ${ }^{\mathrm{TM}} \mathrm{TSV}$ detection) products from haemolymph of 5 Sesarma mederi at $40 \mathrm{~d}$ after feeding with TSV-infected Penaeus (Litopenaeus) vannamei carcasses. Lane M: molecular weight marker. Lane P: positive control (plasmid template with a TSV insert). Lane N: negative control (distilled water template). Lanes showing 2 PCR amplicons (284 and $476 \mathrm{bp}$ ) and a non-specific amplicon above $848 \mathrm{bp}$ indicate heavy infections of TSV

Table 2. Results for RT-PCR detection of TSV in crabs using IQ2000 ${ }^{\mathrm{TM}}$ detection system at various days post-challenge by injection. $+=$ light infection ${ }_{+}++=$medium infection $_{i}+++=$ heavy infection $;-=$ negative infection; values in parentheses indicate no. positive/no. tested

\begin{tabular}{|lcrrrrr|}
\hline Species & $2 \mathrm{~d}$ & $5 \mathrm{~d}$ & $10 \mathrm{~d}$ & $15 \mathrm{~d}$ & $40 \mathrm{~d}$ & $50 \mathrm{~d}$ \\
\hline Sesarma mederi & $+(5 / 5)$ & $+(5 / 5)$ & $+(5 / 5)$ & $+++(5 / 5)$ & $+++(5 / 5)$ & $+++(5 / 5)$ \\
Uca vocans & $+(5 / 5)$ & $+++(5 / 5)$ & $+++(5 / 5)$ & $+++(5 / 5)$ & $+++(5 / 5)$ & $+++(5 / 5)$ \\
Scylla serrata & $-(0 / 5)$ & $++(5 / 5)$ & $+++(5 / 5)$ & $+++(5 / 5)$ & $+++(5 / 5)$ & $+++(5 / 5)$ \\
\hline
\end{tabular}


Table 3. Results for RT-PCR detection of TSV in crabs and palaemonid shrimp using IQ2000 ${ }^{\mathrm{TM}}$ detection system at various days post-challenge by feeding. $+=$ light infection ${ }_{i}++=$ medium infection $_{i}+++=$ heavy infection $;-=$ negative infection ${ }_{i}$ values in parentheses indicate no. positive/no. tested; nd = not done

\begin{tabular}{|c|c|c|c|c|c|c|}
\hline Species & $2 \mathrm{~d}$ & $5 \mathrm{~d}$ & $10 \mathrm{~d}$ & $15 \mathrm{~d}$ & $40 \mathrm{~d}$ & $50 \mathrm{~d}$ \\
\hline Sesarma mederi & $-(0 / 5)$ & $+(3 / 5)$ & $++(4 / 5)$ & $++(5 / 5)$ & $++(5 / 5)$ & $+++(5 / 5)$ \\
\hline Uca vocans & $-(0 / 5)$ & $+(4 / 5)$ & $+++(3 / 5)$ & $+++(4 / 5)$ & $+++(5 / 5)$ & $+++(5 / 5)$ \\
\hline Scylla serrata & $-(0 / 5)$ & $-(0 / 5)$ & $-(0 / 5)$ & $+++(4 / 5)$ & $+++(5 / 5)$ & $+++(5 / 5)$ \\
\hline Palaemon styliferus & $+(5 / 5)$ & $+++(4 / 5)$ & $+++(4 / 5)$ & $-(0 / 5)$ & $-(0 / 5)$ & nd \\
\hline Macrobrachium lanchesteri & $+(5 / 5)$ & $++(4 / 5)$ & $++(4 / 5)$ & $-(0 / 5)$ & $-(0 / 5)$ & nd \\
\hline
\end{tabular}

5 d post-challenge, 4 of 5 P. styliferus showed heavy viral loads, while $M$. lanchesteri gave only medium viral loads. However, both species gave negative test results at $15 \mathrm{~d}$ post-challenge. For control groups all palaemonid shrimp survived and gave negative reactions for TSV at 2, 5, 15 and $50 \mathrm{~d}$.

\section{Confirmation of TSV infections by immunofluorescence and confocal microscopy}

To confirm the presence of TSV infections, 3 individuals of 3 species of crabs at $50 \mathrm{~d}$ post-challenge were processed for immunofluorescence and confocal microscopy using an antibody reagent specific to VP1 of TSV. Positive immunoreactions with the VP1 antibody (red fluorescence) was seen in the cytoplasm of haemocytes of 3 individuals of Sesarma mederi (Fig. $4 \mathrm{~A}-\mathrm{C}$ ). No positive reactions were observed in negative control crabs (Fig. 4D). Similar positive red immunofluorescence was seen in the cytoplasm of hemocytes from

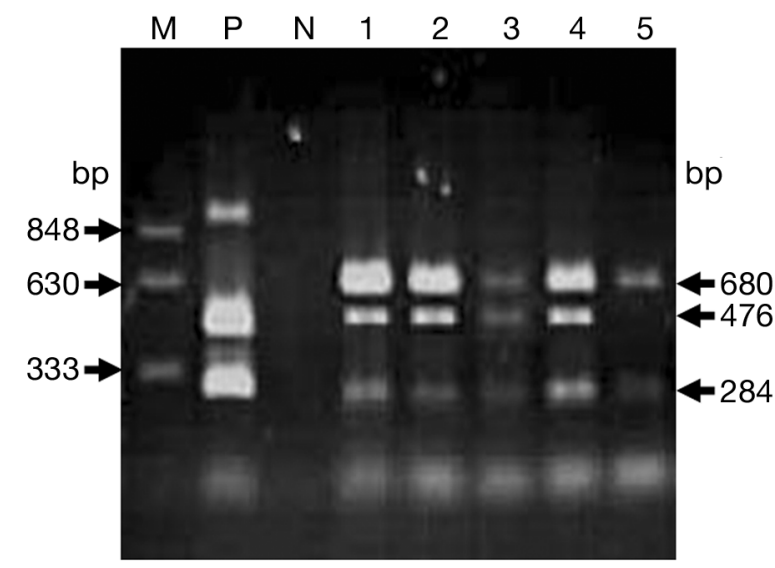

Fig. 3. Sample agarose gel of RT-PCR (IQ2000 TM TSV detection) products from 5 Macrobrachium lanchesteri at $5 \mathrm{~d}$ after feeding with TSV-infected Penaeus (Litopenaeus) vannamei carcasses. Lane M: molecular weight marker. Lane P: positive control (TSV plasmid). Lane N: negative control. Specimens showing PCR products at 284, 476 and $680 \mathrm{bp}$ (housekeeping gene) had medium infections of TSV. Specimens showing PCR products at 284 and $680 \mathrm{bp}$ had light infections the positive control, TSV-infected Penaeus (Litopenaeus) vannamei (Fig. 5A), but not in the cytoplasm of hemocytes from $P$. vannamei negative for TSV by RTPCR (Fig. 5B).

\section{Preliminary transmission experiments}

To test whether TSV could transmit from crabs and palaemonid shrimp to Penaeus (Litopenaeus) vannamei by water, TSV-infected Sesarma mederi and Macrobrachium lanchesteri were placed in aquaria with uninfected $P$. vannamei. All $5 P$. vannamei kept as cohabitants with TSV-infected $S$. mederi showed heavy TSV viral loads at $5 \mathrm{~d}$ (Fig. 6A) and died by $10 \mathrm{~d}$ after the start of cohabitation. All 5 P. vannamei cohabitants with infected M. lanchesteri showed light TSV viral loads at $5 \mathrm{~d}$ after the start of cohabitation and heavy viral loads at $10 \mathrm{~d}$. All were dead by $12 \mathrm{~d}$.

To test whether TSV could transmit from crabs and palaemonid shrimp to Penaeus (Litopenaeus) vannamei by the oral route, the carcasses of TSV-infected Sesarma mederi and Macrobrachium lanchesteri were fed to $P$. vannamei. All $P$. vannamei fed with TSVinfected $S$. mederi (Fig. 6B) and M. lanchesteri gave heavy viral loads by $5 \mathrm{~d}$ after feeding and all died by $8 \mathrm{~d}$ after feeding. However, $P$. vannamei not exposed to TSV in control aquaria gave negative RT-PCR reactions (Fig. 6C) and showed no mortality.

\section{DISCUSSION}

The present study has very clearly shown that the 3 crab species studied can be infected with TSV by injection and by feeding with TSV-infected shrimp carcasses, and that the resulting infections can persist for up to $50 \mathrm{~d}$. Similarly, it has been reported that Sesarma mederi, Scylla serrata and Uca pugilator are susceptible to WSSV infection and may carry it for life (Lo et al. 1996, Kanchanaphum et al. 1998, Peng et al. 1998). By contrast, we found that TSV infections in Palaemon styliferus and Macrobrachium lanchesteri could not be 

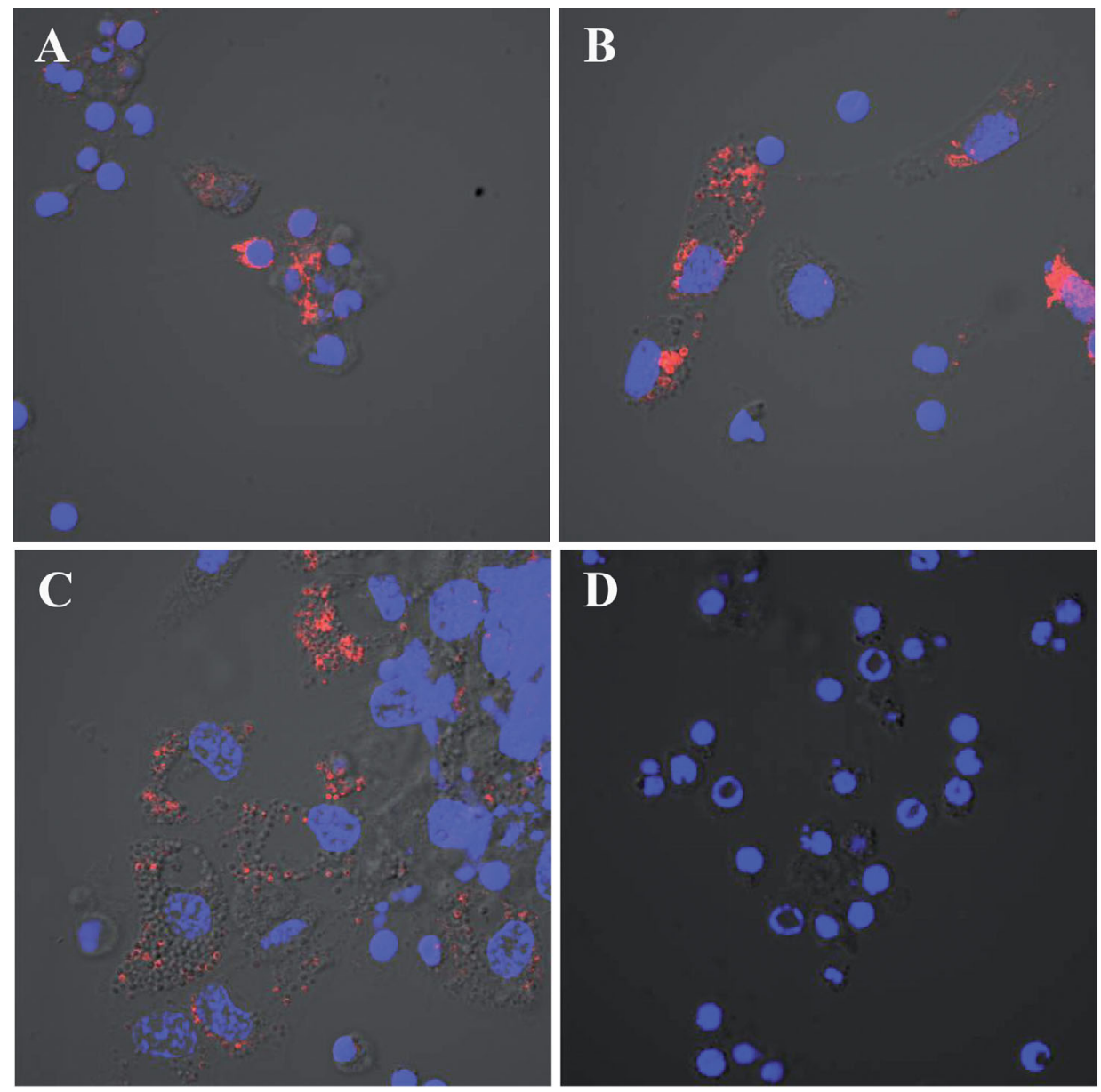

Fig. 4. Sesarma mederi. Sample confocal microscope photographs of immunofluorescence from TSV-infected crabs. (A,B,C) 3 individuals of $S$. mederi showing positive red fluorescence for anti-VP1 of TSV in the cytoplasm of hemocytes. (D) Negative control for $S$. mederi. Blue signal shows TO-PRO-3 iodide staining of DNA for nuclei
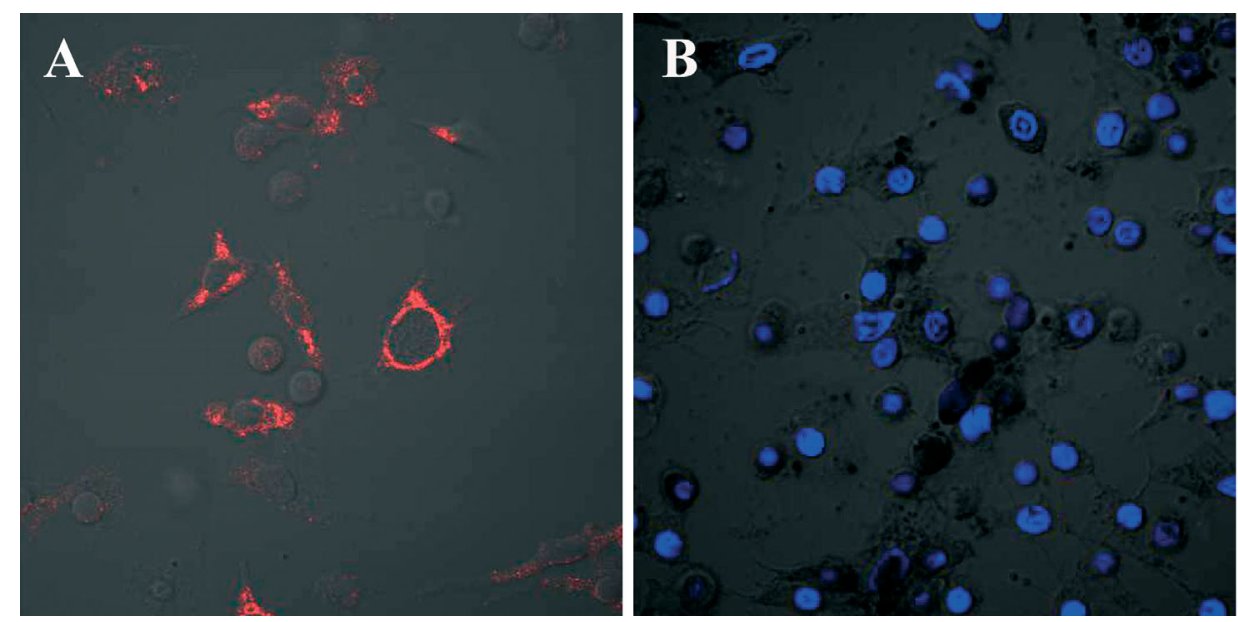

Fig. 5. Penaeus (Litopenaeus) vannamei. Confocal microscope photographs of immunofluorescence tests for TSV in hemocytes. (A) Positive red fluorescence for anti-VP1 of TSV in the cytoplasm of hemocytes of $P$. vannamei challenged with TSV. (B) Negative control for unchallenged $P$. vannamei that tested negative for TSV by RT-PCR and showed no reaction with anti-VP1. Blue signal shows TO-PRO-3 iodide staining of DNA in nuclei 

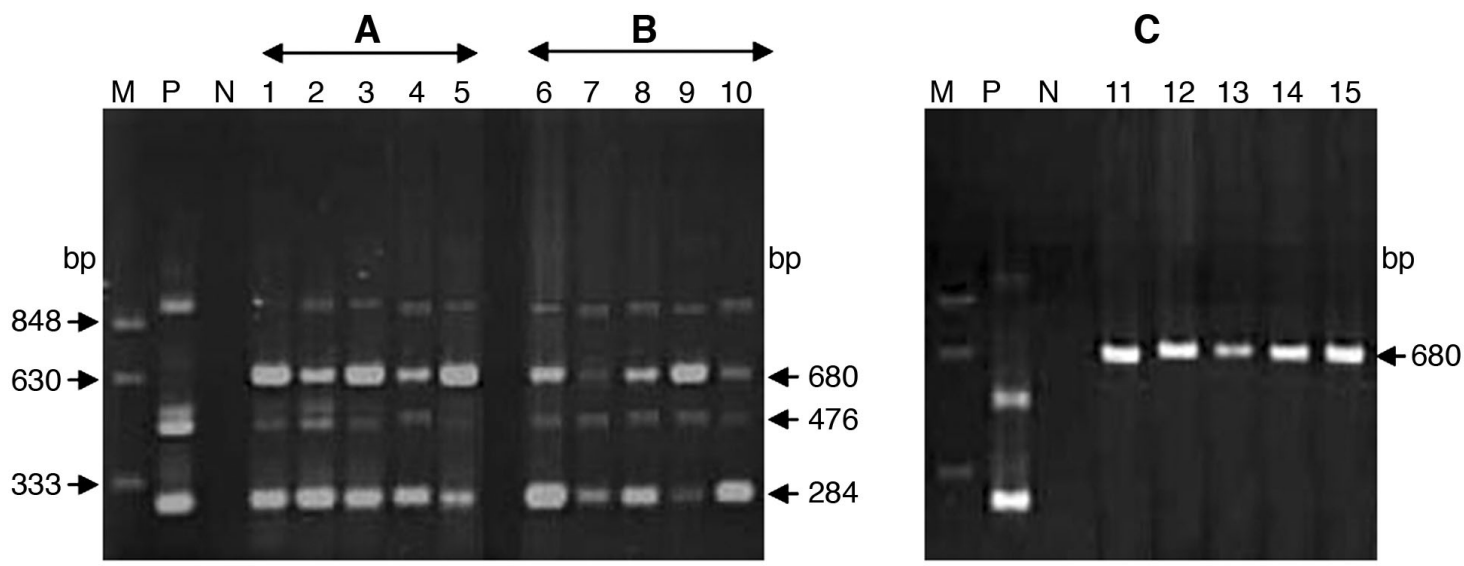

Fig. 6. Penaeus (Litopenaeus) vannamei. Example of assay results for TSV detection by RT-PCR in haemolymph. (A) Results for 5 individual P. vannamei $5 \mathrm{~d}$ after cohabitation with TSV-infected Sesarma mederi (Lanes 1 to 5). (B) Results for 5 individual $P$. vannamei 5 d after feeding with TSV-infected $S$. mederi carcasses (Lanes 6 to 10). (C) Results for 5 individual $P$. vannamei in the control tank (i.e. not exposed to TSV) (Lanes 11 to 15). Lane M: molecular weight marker. Lane P: positive control (plasmid containing target TSV fragment). Lane N: negative controls (distilled water template). Lanes showing 2 PCR amplicons (284 and 476 bp) and a non-specific amplicon above 848 bp indicate heavy TSV infections. PCR products showing a 680 bp band (housekeeping gene product) indicate absence of TSV at the detection limit of 20 genome copies per PCR reaction tube

detected from 15 d post-challenge onwards, suggesting that they were able to clear the virus from their systems. Similarly, Longyant et al. (2005) have reported that $M$. lanchesteri develops very mild yellow head virus (YHV) infections that are detectable at $3 \mathrm{~d}$ postchallenge but not after $10 \mathrm{~d}$. The current study establishes the fact that crabs and to a lesser extent palaemonid shrimp may act as carriers of TSV. However, the degree of risk for disease transfer from these carriers to farmed shrimp would have to be determined by examining a number of other epidemiological factors.

It is interesting that RT-PCR test results for the palaemonid shrimp orally challenged with TSV initially indicated light or negative infections and later medium or heavy viral loads before becoming negative. This revealed that the virus multiplied in the shrimp (i.e. they are susceptible to TSV infection) but that they were able to clear it from their systems. The mechanism for this clearance would be of considerable interest to those studying crustacean immunity. Fortunately, these small shrimp species can be handled easily in the laboratory and would make excellent models for further study.

Although our challenge tests showed that native Thai crustaceans are potential carriers of TSV, transmission studies are needed to determine the degree of danger they might pose for shrimp farmers. Our very preliminary transmission experiments in aquaria revealed that transmission from infected crabs or palaemonid shrimp to Penaeus (Litopenaeus) vannamei is possible through the water or by ingestion of infected carcasses. However, our inability to find wild crustaceans infected with TSV in farm areas where
TSV outbreaks had previously occurred suggests that the prevalence of infected carriers there was not high. Altogether, it would appear that the most dangerous scenario would be for a TSV outbreak to occur in a pond of farmed $P$. vannamei and for wild crustaceans (especially crabs) to have the opportunity to eat infected shrimp carcasses. They would have a high chance of becoming infected and could possibly carry the virus to an uninfected pond where the risk of transmission would be high if they died and were eaten by $P$. vannamei.

In conclusion, it is possible that Thai farmers who buy SPF stocks of Penaeus (Litopenaeus) vannamei certified to be free of TSV could experience TSV outbreaks in their ponds as a result of horizontal transmission from wild, native crabs infected with TSV. However, the normal Thai practice of eliminating wild crustaceans from rearing ponds prior to stocking PL at the beginning of each crop cycle, filtration to eliminate potential vectors or carriers from exchange water during culture and the use of crab exclusion nets should constitute effective control measures.

Acknowledgements. This work was supported by the National Center for Genetic Engineering and Biotechnology (BIOTEC) and L'Oreal Thailand 'for Women in Science' fellowship 2005. We thank A. Boonnud for providing the animals used in this study.

\section{LITERATURE CITED}

Bonami JR, Hasson KW, Mari J, Poulos BT, Lightner DV (1997) Taura syndrome of marine penaeid shrimp: characterization of the viral agent. J Gen Virol 78:313-319 
Boonyaratpalin S, Supamataya K, Kasornchandra J, Direkbusarakom S, Aekpanithanpong U, Chantanachookhin C (1993) Non-occluded baculo-like virus, the causative agent of yellow-head disease in the black tiger shrimp Penaeus monodon. Fish Pathol 28:103-109

Brock JA, Gose RB, Lightner DV, Hasson K (1995) An overview on Taura syndrome, an important disease of farmed Penaeus vannamei. In: Browdy CL, Hopkins JS (eds) Swimming through troubled water. Proceedings of the special session on shrimp farming, Aquaculture '95. World Aquaculture Society, Baton Rouge, LA, p 84-94

Cameron A (2002) Survey toolbox for aquatic animal diseases; a practical manual and software package. Australian Centre for International Agricultural Research, Canberra

Chaivisuthangkura $\mathrm{P}$, Tejangkura $\mathrm{T}$, Rukpratanporn S, Longyant S, Sithigorngul W, Sithigorngul P (2006) Polyclonal antibodies specific for VP1 and VP3 capsid proteins of Taura syndrome virus (TSV) produced via gene cloning and expression. Dis Aquat Org 69:249-253

Chang YS, Peng SE, Yu HT, Liu FC, Wang CH, Lo CF, Kou GH (2004) Genetic and phenotypic variations of isolates of shrimp Taura syndrome virus found in Penaeus monodon and Metapenaeus ensis in Taiwan. J Gen Virol 85: 2963-2968

Chen LL, Lo CF, Chiu YL, Chang CF, Kou GH (2000) Natural and experimental infection of white spot syndrome virus (WSSV) in benthic larvae of mud crab Scylla serrata. Dis Aquat Org 40:157-161

Erickson HS, Zarain-Herzberg M, Lightner DV (2002) Detection of Taura syndrome virus (TSV) strain differences using selected diagnostic methods: diagnostic implication in penaeid shrimp. Dis Aquat Org 52:1-10

Hasson KW, Lightner DV, Poulos BT, Redman RM, White BL, Brock JA, Bonami JR (1995) Taura syndrome in Penaeus vannamei: demonstration of a viral etiology. Dis Aquat Org 23:115-126

Jimenez R (1992) Sindrome de Taura (resumen). In: Acuacultura del Ecuador. In: Jimenez R (ed) Revista especializada de la Camara Nacional de Acuacultura. Guayaquil, p 1-16

Jiravanichpaisal P, Bangyeekhun E, Söderhäll K, Söderhäll I (2001) Experimental infection of white spot syndrome virus in freshwater crayfish Pacifastacus leniusculus. Dis Aquat Org 47:151-157

Kanchanaphum P, Wongteerasupaya C, Sitidilokratana N, Boonsaeng V and others (1998) Experimental transmission of white spot syndrome virus (WSSV) from crabs to shrimp

Editorial responsibility: Timothy Flegel,

Bangkok, Thailand
Penaeus monodon. Dis Aquat Org 34:1-7

> Lo CF, Ho CH, Peng SE, Chen $\mathrm{CH}$, and others (1996) White spot syndrome baculovirus (WSBV) detected in cultured and captured shrimp, crabs and other arthropods. Dis Aquat Org 27:215-225

Longyant S, Sithigorngul P, Chaivisuthangkura P, Rukpratanporn S, Sithigorngul W, Menasveta P (2005) Differences in susceptibility of palaemonid shrimp species to yellow head virus (YHV) infection. Dis Aquat Org 64:5-12

- Maeda M, Itami T, Mizuki E, Tanaka R and others (2000) Red swamp crawfish (Procambarus clarkii): an alternative experimental host in the study of white spot syndrome virus. Acta Virol 44:371-374

> Mari J, Poulos BT, Lightner DV, Bonami JR (2002) Shrimp Taura syndrome virus, genomic characterization and similarity with member of the genus Cricket paralysis-like viruses. J Gen Virol 83:915-926

- Mayo MA (2002) A summary of taxonomic changes recently approved by ICTV. Arch Virol 147:1655-1656

> Mayo MA (2005) Changes to virus taxonomy 2004. Arch Virol 150:189-198

> Nielsen L, Sang-oum W, Cheevadhanarak S, Flegel TW (2005) Taura syndrome virus (TSV) in Thailand and its relationship to TSV in China and the Americas. Dis Aquat Org 63:101-106

Overstreet RM, Lightner DV, Hasson KW, Mcllwain S, Lotz JM (1997) Susceptibility to Taura syndrome virus of some penaeid shrimp species native to the Gulf of Mexico and the Southeastern United States. J Invertebr Pathol 69: $165-176$

Peng SE, Lo CF, Ho CH, Chang CF, Kou GH (1998) Detection of white spot baculovirus (WSBV) in giant freshwater prawn Macrobrachium rosenbergii using polymerase chain reaction. Aquaculture 164:253-262

Supamattaya K, Hoffmann RW, Boonyaratpalin S, Kanchanaphum P (1998) Experimental transmission of white spot syndrome virus (WSSV) from black tiger shrimp Penaeus monodon to the sand crab Portunus peagicus, mud crab Scylla serrata and krill Acetes sp. Dis Aquat Org 32:79-85

Tsai JM, Shiau LJ, Lee HH, Chan PWY, Lin CY (2002) Simultaneous detection of white spot syndrome virus (WSSV) and Taura syndrome virus (TSV) by multiplex reverse transcription-polymerase chain reaction (RT-PCR) in pacific white shrimp Penaeus vannamei. Dis Aquat Org 50:9-12

Submitted: January 4, 2007; Accepted: January 31, 2008

Proofs received from author(s): April 8, 2008 